other cranial bones fitted together, the bi-parietal diameter was computed to be three inches. All the bones had the normal amount of ossification of a full-time foetus.

Points of interest in this case are: 1 . The difficulty of diagnosis, though, looking back now, nothing can be clearer than the sequence of events. 2. The maturity and perfect formation at which the foetus arrived. 3. The means taken by Nature to aemedy her error, and which resulted in perfect recovery.

King's Lynn.

\section{A SUGGESTED ALTERATION IN THE COMPOUND LIQUORICE POWDER.}

By MaRtin OxLeY, M.D.

HAVING found that the above preparation produced very severe griping in many instances where $I$ had ordered it, the griping being particularly severe in some of my younger patients, I have ordered the following formula for some time past, in which anise fruit is substituted instead of the fennel and one-fourth part of ginger is added. The altered formula runs thus-senna and liquorice-root, of each 2 parts; anise fruit and sulphur, of each 1 part; sugar, $5 \frac{a}{4}$ parts; ginger, $\frac{1}{1}$ part. This altered preparation is quite as satisfactory in its laxative properties, is less liable to gripe, and is as pleasant to talke as the official powder, and I would suggest its trial in cases where the powder as now prepared produces the disagreeable effects to which I have referred.

Liverpool.

\section{DOUBLE FRACTURE OF THE UPPER LIMB BY INDIRECT VIOLENCE.}

By ALEX. FoUlerton, M.R.C.S., L.R.C.P.,

RESDEAT MEDICAL OFIICER, ROYAL ISLE OF WIGHT INFIRMARY.

THE following is noteworthy as a somewhat curious result of indirect violence applied to the upper extremity.

A child, aged nineteen months, was being led along the street by his mother, who was holding his right hand. The child stumbled, fell with a jerk, and was dragged up againroughly, probably - by his mother, who, however, never left go of his hand. She then noticed that the boy's arm was quite powerless, and hung loosely by his side. Shortly afterwards the child was brought to the infirmary, where it was found that two fractures had occurred, one through the upper epiphysial line of the right radius, the other at the junction of the middle with the acromial third of the right clavicle. One would certainly have expected dislocation rather than fracture as the result of such an accident occurring in so young a child, and I must confess I am unable to offer any exact explanation as to the mechanics of the lesion.

Isle of Wight.

\section{de âtlitror}

\section{or \\ HOSPITAL PRACTICE, BRITISH AND FOREIGN.}

Nulla autem est alia pro certo noscendi via, nisi quamplurimas et morborum et dissectionum historias, tum aliorum tum proprias collectas habere, et inter se comparare.-MoradanI De sed. et Caus, Morb., lib. iv. Proœmium.

\section{LONDON HOSPITAL.}

A CASE OF PRIMARY CANCER OF THE VAGINA, LEADING

TO RETENTION OF URINE; NECROPSY; REMARKS.

(Under the care of Dr. Herman.)

IT is not usual for epithelioma (for such the disease in this case probably was) of the vagina to produce retention of urine; in the majority of instances the ulcerative process extends, and by the establishment of a fistulous communication with the bladder, causes incontinence. The difficulty met with by the surgeon in alleviating the effects of this may occasion him much anxiety, whilst it is a serious addition to the suffering caused by the disease. There is, however, a great difference between such opening and that produced and controlled by the surgeon; the opening in this case appears to have relieved the retention, and also the pain, which was produced both by the passage of a catheter and the flow of urine over the ulcerated surface.

M. S-, aged forty-one, married, was admitted into Victor ward on Oct. 10th, 1883. She began to menstruate at the age of eleven, and after the age of twelve was always regular except during pregnancy, the flow lasting four or five days, being moderate in quantity and without pain. She was married at the age of sixteen, and in the first fourteen years of married life gave birth to eleven children, two of the pregnancies being with twins. She also had two miscarriages. Of the children only two are now living. Thirteen years ago, during one of her pregnancies, she had some kind of fit. With this exception she has always had gond health. For the last ten years she has been employed as a monthly nurse. The patient thought herself well until seven months ago; then, while exerting herself more than usual, she suddenly felt a sharp pain in the lower part of the abdomen, like a sprain, and on subsequently sitting down she felt a "bearing-down" pain. This has continued ever since. A little later in the day she had a "flooding," losing, she considered, a pint or two of blood. This made her feel extremely faint. Hæmorrhage continued for about three days, and then was replaced by a white vaginal discharge. A discharge has been present ever since, but about six weeks before admission it became yellow and offensive. For the last six weeks she has suffered from scalding pain during and after micturition. For the same time the glands in the left groin have been enlarged and hard, but she has not had any pain in them. A day or two before admission she discovered similar enlargements in the right groin. Throughout the past seven months she has been progresively losing flesh. The day before admission she found herself for the first time unable to pass urine. This inability continuing she came to the hospital, where the urine was drawn off and the patient admitted.

Condition on admission.-The patient is much wasted. The glands in both groins are indurated and enlarged, the left being the larger and fixed. On vaginal examination the anterior wall of the vagina is much thickened, very hard, uneren, and ulcerated. The thickening is especially marked at the lower part, where the induration involves the meatus urinarius. There is an isolated hard lump in the left labium. The cervix uteri is healthy but there is a hard lump to the right of it. The urine is acid; sp. gr. 1010 ; no albumen, pus, or phosphatic deposit. No physical signs of disease elsewhere.

Oct. 26th.-The patient has passed urine naturally since admission, but is now again unable to do so. Dr. A. J. Richardson (resident accoucheur) tried to pass a catheter, but found the urethra so surrounded and blocked with new growth that he was unable to get the catheter through it. The patient was then put into a hot bath, and twenty minims of tincture of opium given. These measures had no effect, and therefore the bladder was aspirated through the vagina.

27th.-Under anæsthesia a catheter was passed, and left in the urethra for the next three days. It was then removed, and the patient was able to pass urine naturally.

Nov. 13th.-The patient again had retention of urine, which has been relieved by the catheter. The glands in the left groin have ulcerated, and the left labium is oedematous.

16th. - The patient continues unable to pass urine. The catheter can be passed, but its use causes extreme suffering to the patient. The bladder was therefore opened by an incision from the vagina, and a winged indiarubber tube put into the opening to keep it patent. After this had been done the patient was in comparative comfort. There is now slight cedema of the right thigh.

28th.-Delirious. The whole of the right leg is odematous.

On Dec. 11th death occurred. The necropsy showed cancer of inguinal glands on both sides, those on the left ulcerated. Bladder contracted, capable of holding an ounce and a half of fluid. Cancer of anterior vaginal wall and urethra, extending along posterior wall of bladder. Kidneys sacculated, especially the right, which only weighed two ounces, left three ounces. Right ureter distended with urine. Right ovary cancerous, and the size of a walnut. Uterus not diseased. Secondary deposit in liver.

Remarks by Dr. HrRMAN.-The case is an interesting example of a rare form of disease, and of a rare event in the history of that disease. Cancer of the uterus often extends 